\title{
SIMULTANEOUS QUANTITATIVE RESOLUTION AND VALIDATION OF A BINARY MIXTURE IN A PHARMACEUTICAL DOSAGE FORM BY USING A SPECTROPHOTOMETRIC SIGNAL PROCESSING TECHNIQUE
}

\author{
FARMASÖTIK BIR PREPARATTAKI IKILII KARIŞIMIN SPEKTROFOTOMETRIK \\ SINYAL IŞSEME TEKNİĞI KULLANILARAK AYNI ANDA MIKTAR TAYINİ VE \\ VALIDASYONU
}

\section{Özgür ÜSTÜNDAĞ $\breve{~}^{*}$ Erdal DİNÇ}

Ankara University, Faculty of Pharmacy, Department of Analytical Chemistry, Ankara, Turkey

\begin{abstract}
Objective: In this context, a rapid and powerful signal processing approach, a ratio-derivative spectrophotometry (RDS) method were developed for the simultaneous determination of irbesartan (IRB) and hydrochlorothiazide (HCT) in a tablet.

Material and Method: The RDS method was applied to the UV spectra of the IRB and HCT. The calibration equations were obtained by measuring amplitudes at $236.3 \mathrm{~nm}$ for the IRB determination and at $260.0 \mathrm{~nm}$ for the HCT determination, respectively. The proposed method was validated by using the recovery studies, intra-day and inter-day assays and standard addition technique.

Result and Discussion: This study aims to apply a rapid and powerful signal processing method to the simultaneous quantification of IRB and HCT in their synthetic mixtures and tablets. As can be seen, the UV spectra of two drugs overlapped strongly in same spectral region. Direct conventional absorbance measurements do not give expected results for the IRB-HCT tablet analysis mainly due to the spectral interference. However, in order to reach a reasonable spectral analysis outcome, we focused mainly on the application of the ratio-derivative spectra treatment to the quantitative resolution of IRB-HCT mixtures without having to a separation procedure.
\end{abstract}

Keywords: Derivative, quantitative determination, spectrophotomety, signal processing, validation

\footnotetext{
* Corresponding Author/Sorumlu Yazar: Özgür Üstündağ

e-mail / e-posta: ustundag@ pharmacy.ankara.edu.tr
} 


\section{ÖZ}

Amaç: Bu çalışmada, tablette irbesartan (IRB) ve hidroklorotiyazidin (HCT) aynı anda miktar tayini için hızlı ve güçlü bir sinyal işleme yaklaşımı, spektrum oranları türev spektrofotometri (RDS) yöntemi geliştirilmiştir. RDS yöntemi, IRB ve HCT'nin UV spektrumlarına uygulanmıştır.

Gereç ve Yöntem: Kalibrasyon denklemleri, sırasıyla IRB tayini için $236.3 \mathrm{~nm}$ 'de ve HCT tayini için 260.0 nm'de ölçülerek elde edilmiştir. Önerilen yöntem, geri kazanım çalışmaları, gün içi ve günler arası testler ve standart ekleme tekniği kullanılarak doğrulanmıştır.

Sonuç ve Tartışma: Bu çalışma, IRB ve HCT'nin sentetik karışımları ve tabletlerinde aynı anda miktar tayini için hızlı ve güçlü bir sinyal işleme yöntemi uygulamayı amaçlamaktadır. Görülebileceği gibi, iki ilacın UV spektrumları aynı spektral bölgede güçlü bir şekilde örtüşmektedir. Doğrudan geleneksel absorbans ölçümleri, spektral girişim nedeniyle IRB-HCT tablet analizi için beklenen sonuçlarl vermemektedir. Bununla birlikte, makul bir spektral analiz sonucuna ulaşmak için, esas olarak spektrum oranlarl türev spektrofotometri işleminin IRB-HCT karışımlarının kantitatif tayinine bir ayırma prosedürüne gerek kalmadan uygulanmasına odaklanılmıştır.

Anahtar Kelimeler: Kantitatif tayin, spektrofotometri, sinyal işleme, türev, validasyon

\section{INTRODUCTION}

New analytical methods or approaches play an increasingly important role in practical applications such as biomedical, clinical, pharmaceutical analysis, environmental monitoring, quality control of industrial manufacturing and forensic science. For these purposes, analytical chemists work to develop more powerful methods and to improve the reliability of existing analytical techniques to meet the demands for better chemical measurements in many fields of science as well as the above mentioned areas [1-3].

As described above, the analytical methods e.g. spectrophotometry [4], mass spectrometry [5], chromatography [6], electrophoresis [7], electrochemistry [8] and their combined devices have been used for analytical aims. For example, the separation techniques, LC and CE combined with various spectroscopic systems (hyphenated techniques namely LC-MS and CE-MS) have been applied to provide additional chemical information and to decrease the complexity of multicomponent mixtures in material analyses. In addition, LC method has been proposed as main or comparison method for the analysis of active compounds in pharmaceutical preparations and other samples. In applications, these chromatographic analysis approaches require a preliminary separation and other tedious analytical processes during analysis for searching optimal separation and other chromatographic conditions. In addition to that, these methods using the combined devices bring high cost and time-consuming for analysis [9-11]. Therefore, the separation methods based on high technology may not provide successful analytical results in some cases.

Due to the mentioned disadvantageous of the above separation techniques or combined analytical devices, analytical chemists prefer the spectroscopic methods (instead of separation 
techniques) for rapid analysis with low cost and successful outcome. Particularly derivative spectrophotometry and its modified versions have been intensively utilized in fast quantitative resolution of multi-component mixtures without separation step. However, in all cases, these spectral methods may not lead good analytical results due to characteristics of strongly overlapping spectra of compounds, interference of main peaks with noise, baseline problems, decreasing signal intensity and worsening signal-to-noise ratio $(\mathrm{S} / \mathrm{N})$ for higher derivative orders [12]. In this context, to overcome the drawbacks of the above traditional methods, analytical chemists need to develop new signal analysis techniques, approaches or methods for the efficient quantitative resolution of complex mixtures. Recent developments in signal processing methods give us more opportunity for the better quantitative resolution of the complex analytical problems as well as other areas of science $[13,14]$. One of the newest additions is ratio-derivative spectrophotometry (RDS) method for the spectral quantification of compounds in mixtures [15]. Ratio-derivative spectrophotometry (RDS) method has gained wide acceptance as a valuable tool for signal processing tasks, due to their wide range of applications.

Several analytical methods, including derivative spectrophotometric methods (16-18) and high performance liquid chromatographic methods (19-22) were reported for the analysis of IRB and HCT in pharmaceutical and biological studies.

In this context, a rapid and powerful signal processing approach, a ratio-derivative spectrophotometry (RDS) method were developed for the simultaneous determination of irbesartan (IRB) and hydrochlorothiazide (HCT) in a tablet. IRB and HCT mixture is a combination of an angiotensin-II receptor antagonist, irbesartan, and a thiazide diuretic, hydrochlorothiazide. The binary mixture of IRB and HCT, which have closely overlapping spectra. Direct conventional absorbance measurements do not give expected results for the IRB-HCT tablet analysis mainly due to the spectral interference. However, in order to reach a reasonable spectral analysis outcome, we focused mainly on the application of the ratio-derivative spectra treatment to the quantitative resolution of IRB-HCT mixtures without having to a separation procedure. The proposed method was validated by using the recovery studies, intra-day and inter-day assays and standard addition technique.

\section{MATERIAL AND METHOD}

In the UV data collection, the absorption spectra of the compounds and their samples in the spectral region of 200-305 nm were recorded by using a Shimadzu UV-1601 double beam UV-VIS spectrophotometer having a fixed slit width $(2 \mathrm{~nm})$ connected with a computer loaded with Shimadzu 
UVPC software and a LEXMARK E-320 printer. In the application of the approaches, the Microsoft EXCEL and Wavelet Toolbox in Matlab 7.0 software were used for data treatments, regressions and statistical analysis.

\section{Chemicals and commercial tablet product}

A commercial tablet formulation (KARVEZIDE ${ }^{\circledR}$ Tablet, Sanofi-Aventis. Ind., Istanbul, Turkey), containing $150 \mathrm{mg}$ of IRB and $12.5 \mathrm{mg}$ of HCT per tablet was collected from local Turkish market. IRB and HCT reference substances were kindly donated from National Pharm. Ind. Companies, Turkey).

\section{Preparation of standard solutions}

A stock standard solution of IRB and HCT was separately prepared by dissolving $25 \mathrm{mg}$ of each drug in $100 \mathrm{~mL}$ methanol. For the spectral analysis, a calibration series for each drug between 4.0-32.0 $\mu \mathrm{g} \mathrm{mL}^{-1}$ for IRB and 2.0-9.0 $\mu \mathrm{g} \mathrm{mL}^{-1}$ for HCT in the above solvent was prepared from the standard stock solutions. For the standard addition technique, the sample solutions were prepared by adding the stock solution of each compound to tablets at three different concentration levels for six replicates to evaluate the interference of excipients on the analysis. In addition, the sample solutions at three different concentration levels for six times were prepared for testing intra-day and inter-day analysis.

\section{Sample solutions preparation}

For analysis of commercial tablets; twenty tablets containing IRB and HCT were weighed and crushed into fine powder. A quantity of powder equivalent to one tablet was transferred to in 100 $\mathrm{ml}$ volumetric flask and then volume was made up to mark with methanol. The content of the flask was mechanically shaken for $30 \mathrm{~min}$. After filtration, the supernatant was diluted with methanol to obtain final concentrations.

\section{RESULT AND DISCUSSION}

This study aims to apply rapid and powerful signal processing method to the simultaneous quantification of IRB and HCT in their synthetic mixtures and tablets. The UV spectra of IRB and HCT standard series and tablet solution were recorded between 200-305 nm as shown in Figure 1. As can be seen, the UV spectra of two drugs overlapped strongly in same spectral region. 


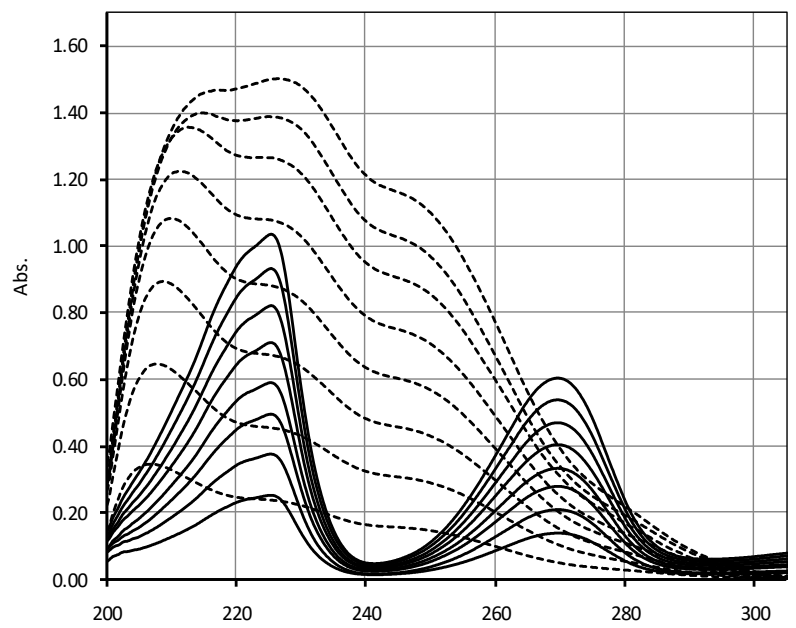

Figure 1. The UV absorption spectra of 4.0-32 $\mu \mathrm{g} \mathrm{mL}^{-1} \mathrm{IRB}(---)$ and $2.0-9.0 \mu \mathrm{g} \mathrm{mL}^{-1} \mathrm{HCT}(-)$ in methanol

Direct conventional absorbance measurements do not give expected results for the IRB-HCT tablet analysis mainly due to the spectral interference. However, in order to reach a reasonable spectral analysis outcome, we focused mainly on the application of the derivative spectra treatment to the quantitative resolution of IRB-HCT mixtures without having to a separation procedure.

The UV spectra of the IRB and HCT, and their tablet solution were recorded in the range 200.0-305.0 $\mathrm{nm}$ and divided by the standard spectrum of $16 \mu \mathrm{g} \mathrm{mL}^{-1} \mathrm{IRB}$. The same procedure was repeated for the standard spectrum of $4 \mu \mathrm{g} \mathrm{mL}^{-1} \mathrm{HCT}$ as a divisor, respectively. The obtained ratio spectrum was also presented in Figure 2. and Figure 3.

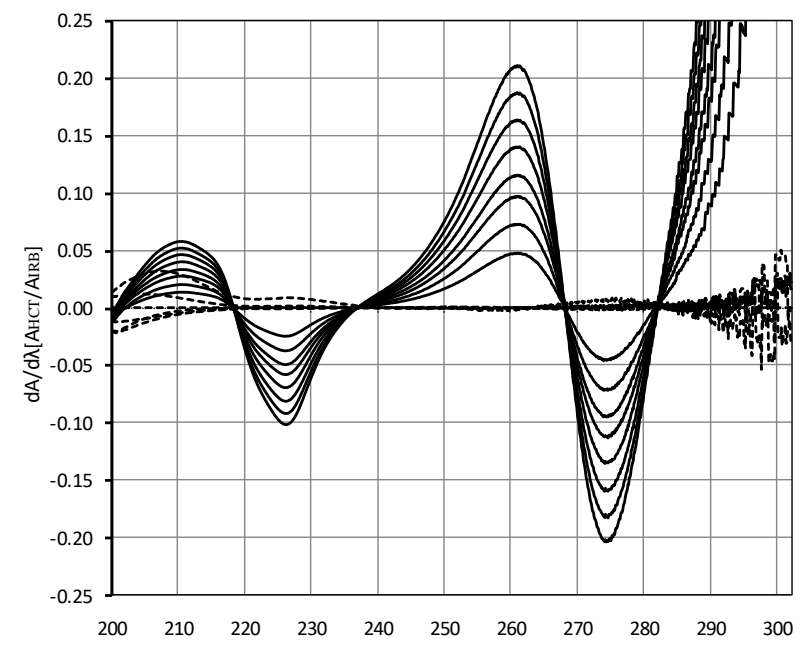

Figure 2. RDS of IRB (---) (4.0-32 $\left.\mu \mathrm{g} \mathrm{mL}^{-1}\right)$ and HCT (-) (2.0-9.0 $\left.\mu \mathrm{g} \mathrm{mL}^{-1}\right)$ in methanol (Div:

$16 \mu \mathrm{g} \mathrm{mL}^{-1} \quad$ IRB $\left.)(\Delta \lambda=10 \mathrm{~nm})\right)$ 


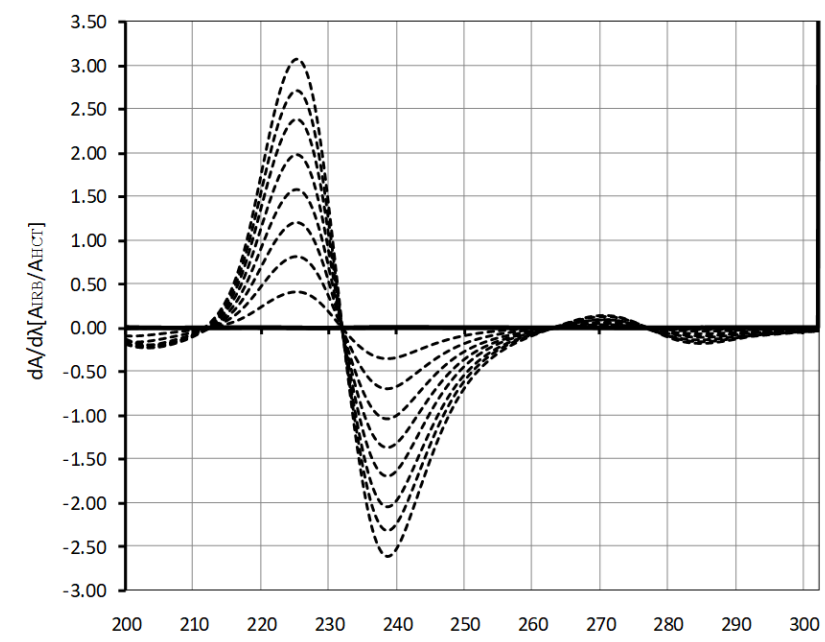

Figure 3. RDS of IRB (---) (4.0-32 $\left.\mu \mathrm{g} \mathrm{mL}^{-1}\right)$ and HCT (-) (2.0-9.0 $\left.\mu \mathrm{g} \mathrm{mL}^{-1}\right)$ in methanol (Div: 4 $\left.\left.\mu \mathrm{g} \mathrm{mL} \mathrm{mL}^{-1} \mathrm{HCT}\right)(\Delta \lambda=10 \mathrm{~nm})\right)$

Obtained regression analysis results can be seen in Table 1.

Table 1. Linear regression analysis and its statistical results for the proposed method

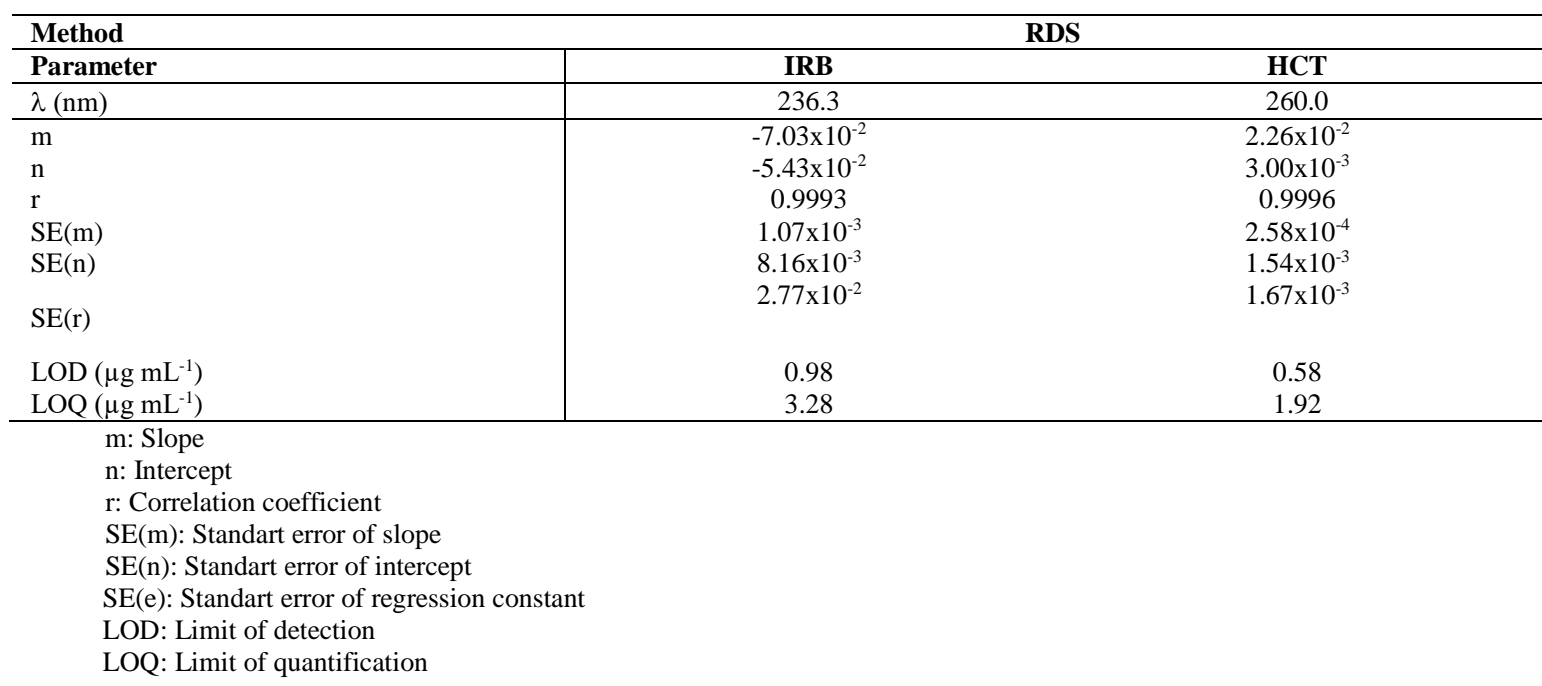

The amount of IRB and HCT in the samples were calculated using the calibration equations calculated according to the linear regression analysis in the Table 1.

\section{Validation of the Proposed Method}

For the validation of the RDS method, a validation set consisting of 16 artificial mixture solutions at different concentrations was prepared in methanol, within the working range of 4.0-32.0 
$\mu \mathrm{g} \mathrm{mL} \mathrm{m}^{-1}$ for IRB and 2.0-9.0 $\mu \mathrm{g} \mathrm{mL}^{-1}$ for HCT. The precision and accuracy of the RDS method was tested using this validation set. The results obtained by applying the RDS method to artificial mixtures prepared as the validation set can be seen in Table2.

Table 2. Recovery results obtained in synthetic mixtures

\begin{tabular}{|c|c|c|c|c|c|}
\hline & & \multicolumn{4}{|c|}{ RDS } \\
\hline \multicolumn{2}{|c|}{$\begin{array}{c}\text { Added } \\
\left(\mu \mathrm{g} \mathrm{mL} L^{-1}\right)\end{array}$} & \multicolumn{2}{|c|}{$\begin{array}{c}\text { Found } \\
\left(\mu \mathrm{g} \mathrm{mL} L^{-1}\right)\end{array}$} & \multicolumn{2}{|c|}{$\begin{array}{c}\text { Recovery } \\
(\%)\end{array}$} \\
\hline IRB & HCT & IRB & HCT & IRB & HCT \\
\hline 30 & 2.0 & 28.98 & 1.94 & 96.6 & 96.9 \\
\hline 30 & 3.0 & 28.73 & 2.93 & 95.8 & 97.6 \\
\hline 30 & 4.0 & 28.90 & 3.95 & 96.3 & 98.7 \\
\hline 30 & 5.0 & 28.73 & 5.01 & 95.8 & 100.3 \\
\hline 30 & 6.0 & 28.81 & 5.99 & 96.0 & 99.9 \\
\hline 30 & 7.0 & 28.72 & 6.96 & 95.7 & 99.4 \\
\hline 30 & 8.0 & 28.82 & 7.81 & 96.1 & 97.7 \\
\hline 30 & 9.0 & 28.65 & 8.85 & 95.5 & 98.3 \\
\hline 4.0 & 2.5 & 4.09 & 2.52 & 102.3 & 100.6 \\
\hline 8.0 & 2.5 & 7.86 & 2.46 & 98.2 & 98.5 \\
\hline 12 & 2.5 & 12.11 & 2.53 & 100.9 & 101.3 \\
\hline 16 & 2.5 & 16.28 & 2.47 & 101.7 & 98.7 \\
\hline 20 & 2.5 & 20.41 & 2.43 & 102.0 & 97.1 \\
\hline 24 & 2.5 & 24.25 & 2.44 & 101.1 & 97.7 \\
\hline 28 & 2.5 & 27.98 & 2.45 & 99.9 & 97.9 \\
\hline \multirow[t]{4}{*}{32} & 2.5 & 31.42 & 2.46 & 98.2 & 98.5 \\
\hline & & & $\overline{\mathrm{X}}$ & 100.6 & 98.5 \\
\hline & & & $\mathrm{SD}$ & 1.41 & 1.46 \\
\hline & & & RSD & 1.40 & 1.48 \\
\hline
\end{tabular}

$\mathrm{SD}=$ Standard deviation

$\mathrm{RSD}=$ Relative standard deviation

To evaluate the accuracy and precision of the RDS method, intra-day and inter-day precision and accuracy studies were performed at three different concentrations $\left(4.0,16.0\right.$ and $30.0 \mu \mathrm{g} \mathrm{mL}^{-1}$ for IRB and 2.0, 5.0, and $8.0 \mu \mathrm{g} \mathrm{mL}^{-1}$ for HCT) within the calibration concentration range. 6 different solutions were used for concentration, and the solutions prepared on the same day and inter days were used (Table 3).

Table 3. Results obtained from the analysis of intra-day and inter-day samples by the proposed method

\begin{tabular}{|c|c|c|c|c|c|c|c|c|c|c|c|c|}
\hline & & \multirow[b]{2}{*}{$\begin{array}{r}\text { Added } \\
\left(\mu \mathrm{g} \mathrm{mL}^{-1}\right)\end{array}$} & \multicolumn{5}{|c|}{ Intra-day $(\mathrm{n}=6)$} & \multicolumn{5}{|c|}{ Inter-day $(\mathrm{n}=6)$} \\
\hline & & & $\begin{array}{c}\begin{array}{c}\text { Found } \\
\left(\mu \mathrm{g} \mathrm{mL}^{-1}\right)\end{array} \\
\end{array}$ & SD & RSD & $\mathrm{RE}$ & Rec. $(\%)$ & $\begin{array}{c}\text { Found } \\
\left(\mu \mathrm{g} \mathrm{mL}^{-1}\right)\end{array}$ & SD & RSD & RSE & Rec. $(\%)$ \\
\hline \multirow{6}{*}{$\stackrel{2}{\underline{a}}$} & \multirow{3}{*}{ 刍 } & 4.0 & 3.92 & 0.08 & 1.92 & -1.90 & 98.1 & 3.93 & 0.08 & 2.01 & -1.72 & 98.3 \\
\hline & & 16.0 & 15.89 & 0.12 & 0.77 & -0.66 & 99.3 & 15.82 & 0.13 & 0.81 & -1.11 & 98.9 \\
\hline & & 30.0 & 29.79 & 0.46 & 1.56 & -0.69 & 100.1 & 29.67 & 0.45 & 1.51 & 3.57 & 96.4 \\
\hline & \multirow{3}{*}{$\underline{\underline{U}}$} & 2.0 & 1.99 & 0.01 & 0.63 & -0.53 & 99.5 & 1.96 & 0.06 & 2.84 & -1.11 & 98.9 \\
\hline & & 5.0 & 4.90 & 0.10 & 1.95 & -2.08 & 97.9 & 4.83 & 0.07 & 1.35 & -3.34 & 96.7 \\
\hline & & 8.0 & 7.93 & 0.13 & 1.60 & -0.82 & 99.2 & 7.75 & 0.18 & 2.31 & -3.34 & 96.8 \\
\hline
\end{tabular}

$\mathrm{SD}=$ Standard deviation

$\mathrm{RSD}=$ Relative standard deviation

$\mathrm{RSE}=$ Relative standard error 
Before applying the RDS signal processing method to the real commercial pharmaceutical preparation, the interference effects of tablet excipients on IRB and HCT compounds were tested. Standard addition technique was used for this purpose (Table 4).

Table 4. Results obtained from the analysis of the standard addition samples by the proposed method

\begin{tabular}{|c|c|c|c|c|c|c|c|c|c|c|c|}
\hline & & Added & & & Recov & & & Mean & $\mathrm{SD}$ & RSD & $\mathrm{RE}$ \\
\hline \multirow{6}{*}{$\stackrel{\mathscr{a}}{\boldsymbol{a}}$} & \multirow{3}{*}{ 苂 } & 4.0 & 98.6 & 100.5 & 98.7 & 102.1 & 100.8 & 100.1 & 1.49 & 1.48 & 0.14 \\
\hline & & 8.0 & 103.7 & 104.8 & 104.8 & 103.5 & 103.3 & 104.0 & 0.73 & 0.70 & 4.02 \\
\hline & & 12.0 & 102.1 & 103.5 & 103.7 & 103.0 & 103.2 & 103.1 & 0.62 & 0.60 & 3.12 \\
\hline & \multirow{3}{*}{$\underline{\Xi}$} & 2.0 & 103.2 & 105.4 & 104.3 & 104.8 & 104.8 & 104.5 & 0.82 & 0.78 & 4.53 \\
\hline & & 4.0 & 102.8 & 103.4 & 102.8 & 102.0 & 102.0 & 102.6 & 0.59 & 0.57 & 2.60 \\
\hline & & 8.0 & 99.6 & 100.2 & 100.3 & 100.2 & 100.2 & 100.1 & 0.26 & 0.26 & 0.09 \\
\hline
\end{tabular}

$\mathrm{SD}=$ Standard deviation

$\mathrm{RSD}=$ Relative standard deviation

$\mathrm{RE}=$ Relative error

Recovery and other calculations were made for IRB and HCT in the added standards by deducting the amount of IRB and HCT coming from the preparation. These studies were carried out with five repetitions at three different concentration levels.

\section{Tablet Results}

Experimental results obtained by the application of the proposed signal processing method to the IRB-HCT tablet samples were indicated in Table 5. Successful results were obtained for the quantitative analysis of commercial tablets containing IRB and HCT compounds. In the tablet analysis, the interference of the tablet excipients on the determination of the related compounds was not observed in application of proposed method to the commercial tablets.

Table 5. Analysis results of tablets containing IRB and HCT by the proposed method

\begin{tabular}{c|c|c}
\hline Method & \multicolumn{2}{|c}{ RDS } \\
\hline & $\begin{array}{c}\text { IRB } \\
(\mathbf{m g})\end{array}$ & $\begin{array}{c}\text { HCT } \\
(\mathbf{m g})\end{array}$ \\
\hline Mean & $147.12 \pm 0,32$ & $12.05 \pm 0,04$ \\
SD & 1.01 & 0.12 \\
RSD & 0.69 & 1.01 \\
CL & 0.63 & 0.08 \\
\hline
\end{tabular}

$\mathrm{SD}=$ Standard deviation,

$\mathrm{RSD}=$ Relative standard deviation

$\mathrm{CL}=$ Confidence limit

In conclusion, a rapid and powerful hyphenated signal processing approach, RDS were developed and applied to the simultaneous spectral quantification of IRB and HCT in their synthetic mixtures and tablets. This signal processing method does not require any separation step for the 
analysis of both compounds having the strong overlapping spectra in the same spectral region (see Figure 1). In order to demonstrate the validity and applicability of the methods, the optimal control processes of the proposed methods were performed by using the analytical validation parameters.

The proposed methods can be used for the quantitative estimation and routine quality control of the tablets containing mentioned drugs.

\section{CONFLICT OF INTEREST}

The authors confirm that this article content has no conflict of interest.

\section{REFERENCES}

1. Siddiqui, M.R., Al Othman, Z.A., Rahman, N. (2017). Analytical techniques in pharmaceutical analysis: A review. Arabian Journal of Chemistry, 10, 1409-1421.

2. Valagaleti, R., Burns, P.K., Gill, M. (2003). Analytical support for drug manufacturing in the United States - from active pharmaceutical ingredient synthesis to drug product shelf life. Drug Inform. J., 37, 407-438.

3. Ju, H. (2013). Grand challenges in analytical chemistry: towards more bright eyes for scientific research, social events and human health. Front. Chem., https://doi.org/10.3389/fchem.2013.00005.

4. El-Didamony, A. M., Saad, M. Z., Saleem, N. O. (2015). Spectrophotometric determination of some analgesic drugs in pharmaceutical formulations using N-bromosuccinimide as an oxidant. Journal of the Association of Arab Universities for Basic and Applied Sciences, 17, 43-50.

5. Baghel, U. S., Singh, A., Singh, D., Sinha, M. (2017). Application of mass spectroscopy in pharmaceutical and biomedical analysis. Spectroscopic Analyses - Developments and Applications, DOI: 10.5772/intechopen.70655

6. Khateeb, L. A., Al-Hakami, W.E. (2020). Reliable chromatographic determination of nonsteroidal anti-inflammatory drugs in real samples matrices. International Journal of Environmental Analytical Chemistry, https://doi.org/10.1080/03067319.2019.1689967.

7. Baciu, T., Botello, I., Borrull, F., Calull, M. Aguilar, C. (2015). Capillary electrophoresis and related techniques in the determination of drugs of abuse and their metabolites. $\operatorname{Tr} A C$ Trends in Analytical Chemistry, 74, 89-108.

8. Özdokur, K. V. (2019). Voltammetric determination of isoniazid drug in various matrix by using $\mathrm{CuOx}$ decorated mw-cnt modified glassy carbon electrode. Electroanalysis, https://doi.org/10.1002/elan.201900307. 
9. Chhonker, Y. S., Edi, C., Murry, D. J. (2018). LC-MS/MS method for simultaneous determination of diethylcarbamazine, albendazole and albendazole metabolites in human plasma: Application to a clinical pharmacokinetic study. J. Pharm. Biomed. Anal., 20-151, 84-90.

10. Sáiz, J., García-Ruiz, C., Gómara, B. (2017). Comparison of different GC-MS configurations for the determination of prevalent drugs and related metabolites. Analytical Methods, 9, 2897-2908.

11. Maurer, H. H. (1994). Toxicological analysis of drugs: GC-MS screening and confirmation. Acta Medicince Legalis, XLIV, 489-492.

12. Daubechies, I. (1992). Ten Lectures on Wavelets, Society for Industrial and Applied Mathematics, Philadelphia, 1-357.

13. Dinç, E., Baleanu, D. (2007). Continuous wavelet transform applied to the overlapping absorption signals and their ratio signals for the quantitative resolution of mixture of oxfendazole and oxyclozanide in bolus. J. Food Drug Anal., 15(2), 109-117.

14. Dinç, E., Baleanu, D., Üstündağ, Ö. (2003). An approach to quantitative two-component analysis of a mixture containing hydrochlorothiazide and spironolactone in tablets by one dimensional continuous daubechies and biorthogonal wavelet analysis of UV-spectra. Spectrosc. Lett., 36, 341-355.

15. Redasani, V. K., Patel, P. R., Marathe, D.Y., Chaudhari, S. R., Shirkhedkar, A. A., Surana, S. J. (2018). A review on derivative uv-spectrophotometry analysis of drugs in pharmaceutical formulations and biological samples review. Journal of the Chilean Chemical Society, http://dx.doi.org/10.4067/s0717-97072018000304126.

16. Albero, I., Rodenas, V., Garcia, S., Sanchez, C. (2002). Determination of irbesartan in the presence of hydrochlorothiazide by derivative spectrophotometry. J. Pharmaceut. Biomed., 29(1-2), 299-305.

17. El-Yazbi, A., Hammud, H., Sonji, M. (2007). Analysis of eprosartan-hydrochlorothiazide and irbesartan -hydrochlorothiazide binary mixtures by derivative spectrophotometry. Int. J. App. Chem., 3(1), 1-12.

18. Joseph, J., Brault, S., Boyer, C., Langlois, M., Cabrero, L., Dubost, J. (2003). Simultaneous determination of irbesartan and hydrochlorothiazide in tablets by derivative spectrophotometry. Anal. Lett., 36(11), 2485-2495.

19. Zhu, J., You, S., Meng, X. (2003). Determination of irbesartan and hydrochlorothiazide in compound irbesartan tablets by HPLC. Zhongguo Yiyao Gongye Zazhi, 34(11), 567-569.

20. Tutunji, L. F., Tutunji, M. F., Alzoubi, M. I., Khabbas, M. H., Arida, A. I. (2009). Simultaneous determination of irbesartan and hydrochlorothiazide in human plasma using HPLC coupled with tandem mass spectrometry:Application to bioequivalence studies. $J$. Pharmaceut. Biomed., 51(4), 985-990. 
21. Alanazi, A. M., Abdelhameed, A. S., Khalil, N.Y., Khan, A. A., Darwish, I. A. (2014). HPLC method with monolithic column for simultaneous determination of irbesartan and hydrochlorothiazide in tablets. Acta Pharm., 64, 187-198.

22. Kalyani, G., Adjuad, B. (2019). Stability indicating assay and estimation of irbesartan by first order uv derivative spectrophotometry. International Journal of Pharmaceutical Sciences and Research, 23, 3817-3821. 